Available online at: https://journals.researchsynergypress.com/index.php/ijmesh

International Journal of Management, Entrepreneurship, Social Science and Humanities

(IJMESH)

ISSN 2580-0981 (online)

Volume 4 Issue 1 (2021): 76-95

\title{
Traces of Ato as a Judicial Institution in the Lupon of Barangay Talubin, Bontoc, Mt. Province
}

\author{
Alexander G. Killip Jr. ${ }^{1}$ \\ ${ }^{1}$ Senior High School Department, University of Baguio, Phillipines
}

\begin{abstract}
Ato shows the existence of the indigenous political institution in the Cordillera specifically in Mt. Province that reflects the cultural patterns, political processes, and assumptions of rights of the community based on their customary laws that allow the indigenous people to achieve meaningful self-determination. The researcher wanted to determine and understand the traces of ato as a judicial institution in the Lupon through its public administration and judicial practices. The researcher made use of qualitative approach and descriptive design to understand the perceptions and beliefs of the Lupon members. Five (5) members of Lupon and three (3) barangay officials discussed the existing judicial and administrative practices of the Lupon. The study found out that the traces of ato as a judicial institution in the Lupon focus on the public administration practices that involve the processes of implementing and evaluating of policies such as the review on the ordinance by the barangay captain, posting of ordinance in the barangay hall and the house-to-house information dissemination by the tanods. The judicial practices on conflict resolution in the Lupon follow a series of trial procedures; first one is the private mediation process of the barangay mediation council that involves only the barangay officers and the conflicting parties; and, the second one is the public trial of the conflict through arbitration by the Lupon members. The judicial practices on imposing sanctions include fine such as money, personal belongings, property, or livestock and community service.
\end{abstract}

Keywords: Ato, Judicial Institution, Lupon, Public administration

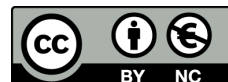

This is an open access article under the CC-BY-NC license

\section{INTRODUCTION}

The Bontoc villagers take pride in themselves as one community (sinpangili) helping each other always to the extent that they declare war against another village if a village mate has been wronged by an outsider. Due to the off and on warfare that disrupts their economic and social life and relationships, the elders of the village, especially those adversely affected by the hostilities exert significant efforts in solving the conflict (Cordillera School Groups, Inc., 2003).

The process of dispute settlement and conflict management varies depending on the most acceptable traditional practice being used in the community. In Bontoc, the primary way of settling disputes is through arbitration by the elders. Arbitration is a process where the third provides the final decision on how to resolve the dispute based on the information presented to him/her by the disputants (Disini Jr., Aguiling- Pangalangan, Daroy-Morales, Gatmaytan, \& Lim 2002).

Dispute settlement and conflict management administration is a way for the public administrators to handle conflicts and disputes. The way public administrators perform their role in conflict resolution can reflect to their competence in implementing the legal norms, 
International Journal of Management, Entrepreneurship, Social Science and Humanities (IJMESH) Vol. 4 (1), 76-95

Traces of Ato as a Judicial Institution in the Lupon of Barangay Talubin, Bontoc, Mt. Province

A. G. Killip Jr

organizational tools, methods of management processes and procedures as a regulatory, organizational and executive body (Mladen (2015).

According to Manengyao (2016), there are numerous reasons of conflict among the Bontoc people that must be addressed through dispute settlement and conflict management. Disputes include conflicts on the boundary, water resources, and crime-related incidents. Prill-Brett (2015) also stressed that traditional politics focuses on cases affecting communal, family or corporate and private lands, dispute on property inheritance, marriage, and family conflict within the Bontoc villages. These types of cases can be settled in a certain ato where both conflicting parties are members within the community. The conflicts that were commonly handled by the Council of Elders fall under property and civil-related disputes.

It is essential to understand the remaining traditional practices of the indigenous political institution such as the ato. In addition, it also is necessary to understand the traces of political and judicial processes of ato in the lupon through the understanding of its judicial and administrative practices.

The findings of the study can help the community of Talubin in understanding the traces of ato as a judicial institution in the Lupon of the Barangay through the determination of the public administration practices of the Lupon in knowing the processes of the implementation and evaluation of its policies. Furthermore, the result of the study can enhance the knowledge of the researcher on the judicial practices of the Lupon on its conflict resolution and imposition of sanctions.

Hence, an analysis of the changes in the political life of the Bontoc people is necessary. Also, it is important to look into how the traditional legal and political practices of the Bontoc people are integrated in the current practices.

\section{OBJECTIVES OF THE STUDY}

The study aimed to determine the traces of Ato as a judicial institution in the Lupon of Talubin, Bontoc, Mt. Province.

Specifically, the research sought answers to the following:

1. To determine the Public Administration practices in the Lupon.

1.1. To determine the processes in implementing policies in the Lupon.

1.2. To determine the processes in evaluating policies in the Lupon.

2. To determine the judicial practices in the Lupon.

2.1. To determine the judicial practices on conflict resolutions in the Lupon.

\section{LITERATURE REVIEW}

Each Bontoc village is politically and economically autonomous from any other authority (Cordillera Schools Groups, 2003; Prill-Brett, 2015). Prill-Brett (2015) also mentioned in her book, Tradition, and Transformation: Studies on Cordillera Indigenous Culture, that village or ili is the largest political institution in Bontoc. Villages are composed of nuclear families occupying single households. They have their boundaries recognized by surrounding villages. Each village has several atos that are considered to be indigenous political institutions within the community. A family is affiliated with one of several atos/actors in a village and is represented by the male household. 
The people of Bontoc believed in the existence of a supreme deity named Kabunian/ Kafunian who has a son called Lumawig. It was believed that Lumawig is a possessor of specific divine properties. He is the representative of his father, and descended from the sky into the earth and married a Bontoc maiden (Fiar-od, 2000; Cawed, 1972).

It is believed that Lumawig, instituted the ato. He designed the ato as the place for carrying on headhunting ceremonies and for holding rituals of the village (Prill-Berett 1987:19, as cited by Cordillera School Groups, Inc., 2003). Cawed (1972) also mentioned that the people of Bontoc believed that Lumawig left his commandments to rule the life of every Igorot. For ages and generations, the commandments left by Lumawig, composed of unwritten code of ethics have come to him and taught him:

1. Never to lie, for the good men do not live with liars;

2. To respect the properties of others, for people must lead good honest lives; and,

3. To be brothers to all men.

An Ato is a political institution (Fiar-od, 2000; Cordillera School Groups, Inc., 2003; PrillBrett, 1987), and described by Jenks (1905) and Tadaoan (1973), as cited by Prill- Brett (1987), as the "government and control of the Pueblo" that serves as a political unit and provides (political) leadership. Ato is a self-perpetuating institution (Jenks, 1905) that consolidates the people and fosters unity by threshing out conflicts among members.

Furthermore, Ato is the meeting place of the elders that serves as the focal point of community unity. These elders comprise a council called "tongtong" who make community decisions as to giving of judgments and sanctions to an accuser or accused person in terms of moral issues (Baring \& Gaspar, 2013). Lastly, Ato assists families beset with problems. It serves as a council where male members converge to discuss vital matters affecting the entire community, such as settling disputes and issuing penalties, declaring wars with neighboring groups or tribes.

Traditionally, no superior external authority is controlling judicial or economic processes within the village, but all authority resides on the ato within the community (Prill-Brett, 2015). The holding of peace pacts is also an essential function of the ato, which ensures the safe passage of its members in the territory of another group (Cordillera School Groups, Inc., 2003).

Each village in Bontoc is composed of more than one ato that caters to separate families. The number of ato from each village varies depending on the size of the population, and each family is affiliated with one of the several atos in the village (Prill-Brett, 2015). However, a village is not merely an aggregate of an independent ato. The village is the largest social group composed of ato coalescing in times of trouble and during the performance of rituals and feast. Thus, there is solidarity among villagers (Cordillera School Groups, Inc., 2003).

Cawed (1972) discussed in her book entitled, "The Culture of the Bontoc Igorot," that an Igorot has four choices of atos which he may become a part of. These are the following:

1. The ato where he was born;

2. The ato of his grandfather;

3. The ato of his father-in-law; and,

4. The ato where he builds his home;

Each family sends male members as representatives in the ato. Only the males can enter the ato and participate in the discussion of community affairs. However, this does not deter women from voicing out their opinions. Before the male representatives go to the ato, they solicit the views 
International Journal of Management, Entrepreneurship, Social Science and Humanities (IJMESH) Vol. 4 (1), 76-95

Traces of Ato as a Judicial Institution in the Lupon of Barangay Talubin, Bontoc, Mt. Province

A. G. Killip Jr

of other members of the family. They undergo deliberation until an agreement is reached (Cordillera School Groups, Inc., 2003).

Cawed (1972) also mentioned that a married householder participates in all activities of his ato. If he is old enough, he becomes a member of the venerated intugtukon (Council of elders) and has a voice in the ato affairs. As a member, therefore, he follows the rules and regulations of his ato, contributes to all ato expenses, and participates in all religious, social, and political activities. The ato may have twenty-five to fifty members.

Membership in an ato is for life. A person may leave the place only if he loses face before his fellow members.

Membership in the Council of Elders. As defined by Cordillera School Groups, Inc. (2003), ingtugtukon is the Council of elders that recognizes no single headman or chieftain. However, some places in Bontoc named them as the Anam-ama Or Anam- a. Prill-Brett (2015) also added that the Council of elders is already the judicial, legislative, and executive body of the ili.

Prill-Brett (2015) also outlined some requirements in order for someone to qualify for membership for the Council of elders. These requirements outline that one must be (1) rich in life experience; (2) articulate, with a record of good judgment in the past deliberation of cases; (3) fair in the formulation of decisions as evidenced by past cases, and by the villager's affirmation of this fact; (4) holder of good war record (although not an absolute necessity, this may give an elder an edge over the others in prestige); and, (5) wealthy (though this requirement is by itself, not sufficient qualification).

The councils of elders are made up of wise older men who are experts in custom laws (Cordillera School Groups, Inc., 2003) and (Cawed, 1972) and are the repository of wisdom (Folkmar, 1962). They are also responsible for making laws and amending them when they see fit, like the legislation of policies/ customary laws like the tengao or obaya (local religious holidays), planning and settling and declaration of dates for the agricultural activities, and determining and implementing of customary laws and policies like the sapata.

Also, the said councils also counsel villagers who needed help (Prill-Brett, 2015). They can declare, accept, or reject war challenges; and if their tribe is at war; it can sue for peace, as it deems right with the enemies. The group decides the activities, rituals, workday, tengao of the villagers (Cawed, 1972); and planning and settling including the declaration of dates for the agricultural activities. The elders do not receive any fixed form of compensation for their services. However, they enjoy social prestige and shares of meat of pigs and other animals for rituals in the ato.

The ato, through its Council of elders, has a definite role in maintaining peace and order in the community. The role of ato always involves dispute resolution and conflict management among the members of the community to achieve a range of social, cultural and economic goals and improved access to justice (National Alternative Dispute Resolution Advisory Council, 2006). The services provided by the Council of elders have the potential to reduce levels of violence within and outside the village. The Council of elders also promotes healing of damaged relationships between indigenous people, and enhance governance and decision-making by the indigenous communities of Bontoc.

However, it was evident that the socio-cultural and political system of some parts of Bontoc are currently undergoing gradual and organic changes as new and liberal ideas influence the new generation. The social changes were caused by the introduction of education and further integration of the youth with the broader community outside Bontoc. However, the people can still

(c) 2021 International Journal of Management, Entrepreneurship, Social Science and Humanities (IJMESH)

ISSN 2580-0981 (online) 
International Journal of Management, Entrepreneurship, Social Science and Humanities (IJMESH) Vol. 4 (1), 76-95

Traces of Ato as a Judicial Institution in the Lupon of Barangay Talubin, Bontoc, Mt. Province

A. G. Killip Jr.

witness the authentic culture of the Bontoc people. The Igorot culture was barely touched by colonizers because even when they were defeated in battles against the Spaniards, never did they give up their cause to preserve their independence. The maintenance of the Igorot culture may also explain why the fundamental contradiction between Spanish Colonial law and native customary law did not become a big deal to the Igorot because Spanish law was nominally and superficially complied with, but customary law was being followed.

Prill- Brett (2015) also stated that several Cordillera groups from different provinces have been undergoing a process of change which may affect their political institutions in varying degrees. A study conducted on the Isneg by Madale (1973), as cited by Prill- Brett (2015,) shows that the indigenous political leadership status in the community has been weakened by the superimposition of current laws of the institutionalized national government of the new qualifications for political leadership.

At present, other than the existence of ato, another local unit of the Barangay is the Katarungang Pambarangay composed of Lupong Tagapamayapa members. The Lupong Tagapamayapa exercises administrative supervisions over conciliation and arbitration of cases that are subject to amicable settlement and arbitration. Section 412 of the Philippine Local Government Code of 1991 provides that the customs and traditions of the community shall apply during conciliation. In addition, the proceedings of the settlement shall be public and informal.

In Bontoc, it is evident especially among the four central barangays of the municipality namely, Poblacion, Caluttit, Bontoc Ili and Samoki which are the center of commerce and business. The role of ato is already shifting from being an administrator of justice and political division to a socio-cultural entity. Also, the role of ato involves the administering of cultural gatherings such as the "pasok-ey" or a traditional Thanksgiving. The political role of the ato such as maintaining peace and order, administering justice and political mobility is already transferred to the Barangay and other agencies of the local government which is a mandate of the Local Government Code of 1991.

However, in some barangays of Bontoc, especially those that are in the nonadjacent places and far from the four (4) central barangays, the role of ato is still intact. An example is Barangay Talubin, one of the barangays in the western part Bontoc. In Talubin, the Katarungang Pambarangay became an alternative avenue for the members of the community to settle civil disputes. The Lupong Tagapamayapa members were appointed by the Barangay Captain based on their capability to administer justice through dispute settlement and conflict management within the Barangay. It is evident that at present, the members of the Katarungang Pambarangay also belong to the Council of elders of the ato.

The researcher conducted an initial interview to some people from Talubin to ask why the local officials of the barangay prioritize the members of the Council of elders to be part of Katarungang Pambarangay. The typical response relates to the perception of the people towards the elders of the community. The people's respect for the elders stems from the elders' wisdom and experience to arbitrate and settle conflicts.

The role of the elders in administering the political life of the indigenous community is linked to the scope and procedures of implementing the indigenous justice system. The concept of justice in Bontoc is based on the established customary laws on settling disputes that were used by the elders of the community and the conscious inculcation of those among the youth of the community (Molintas, 2004). Although some customary laws are still being practiced in some parts of Bontoc up to the present, some customary laws are already abolished or amended in response to 
International Journal of Management, Entrepreneurship, Social Science and Humanities (IJMESH) Vol. 4 (1), 76-95

Traces of Ato as a Judicial Institution in the Lupon of Barangay Talubin, Bontoc, Mt. Province

A. G. Killip Jr

the changes in the community. One example is the penal laws that were once practiced but were considered by the state laws to be bit harsh and inhumane. Some of the examples are recorded by Jenks (1905), who stated that the chief crimes against Igorot society are theft, lying to shield oneself from some criminal act, assault and battery, and murder.

Dispute resolution and conflict management practices are intricately woven into the value and belief system of the community. Traditional ways of dispute resolution and conflict management practices had been recognized by the national government to be vital in preserving the culture and traditions of the indigenous people. Republic Act supported the indigenous justice system. No. 8371, also known as The Indigenous Peoples' Rights Act of 1997 under Section 65 stating that:

"When disputes involve ICCSs/ IPs, customary laws and practices shall be used to resolve the dispute."

\section{Conceptual Framework}

The Local Government Code of 1991 established the Lupong Tagapamayapa or Lupon. The Lupon is composed of the punong barangay as the chairman, and ten (10) to twenty (20) members. The Lupon exercises administrative supervision over the conciliation panel in all disputes involving real property or any social interest in the barangay. In barangays where the majority of the inhabitants are members of indigenous cultural communities, local systems of settling disputes through their councils of datus or elders shall be recognized by the applicable provisions of the Local Government Code of 1991. The following provisions of the Local Government Code of 1991 enumerate the composition, functions, and other pertinent information that are significant to the understanding of the Lupon:

Composition of the Lupon. Lupong Tagapamayapa or referred to as Lupon shall be composed of the punong barangay as the chairman, and ten (10) to twenty (20) members. The members can be any person who is residing or working in the barangay, not otherwise expressly disqualified by law. The candidate for the member of a Lupon shall possess integrity, impartiality, independence of mind, sense of fairness, and reputation for probity. In barangays where the majority of the inhabitants are members of indigenous cultural communities, local systems of settling disputes through their councils of datus or elders shall be recognized without prejudice to the applicable provisions of this code.

Functions of the Lupon. The member of the Lupon shall exercise administrative supervision over the conciliation panel during the arbitration, mediation or conciliation process during the amicable settlement. The Lupon needs to meet regularly, once a month, to provide a forum for the exchange of ideas among its members and the public on matters relevant to the amicable settlement of disputes. The said meeting of the Lupon will also enable various conciliation panel members to share their observation and experiences in effecting the speedy resolution of disputes.

All amicable settlements shall be in writing, a language or dialect known to the parties. The settlement must be signed by both parties and shall be attested by the Lupon chairman or the pangkat chairman. Moreover, no complaint involving any matter within the authority of the Lupon shall be filed or instituted directly in the court or any other government office for adjudication, unless there has been a confrontation between the parties before the Lupon chairman or the pangkat. 


\section{Alternative Dispute Resolution}

The Republic Act No. 9285 also known as "An act to Institutionalize the use of an Alternative Dispute Resolution System in the Philippines and to establish the office for Alternative Dispute Resolution, and for other purposes" declares the policy of the state to actively promote party autonomy in the resolution of disputes or the freedom of the party to make their arrangements. In Barangay Talubin, the party is encouraged to use the Alternative Dispute Resolution (ADR) as an essential means to achieve faster and impartial justice through the Lupong Tagapamayapa. The following provisions of the law identified some critical concepts that are related to the ADR and were laid down through the context of the barangay:

Alternative Dispute Resolution System. Republic Act No. 9285 stated that it is a process of resolving a dispute that involves the participation of the neutral third party, which is not necessarily the court judge. In the indigenous community, the said third parties are the elders or leader of the community who will resolve the conflict because they are known to possess qualities such as wisdom and expertise in arbitration or mediation.

The concepts mentioned above explain the composition, functions, and characteristics of the Lupon as an administrative and judicial body. The said concepts mentioned also explained the administrative supervision of the lupon over the conciliation panel in all disputes involving real property or any social interest in the barangay. Moreover, the framework of the study explains Alternative Dispute Resolution (ADR) as an essential means to achieve faster and impartial justice through the Lupong Tagapamayapa. The use of arbitration or mediation are part of the ADR as a process of resolving the dispute by the lupon.

This researcher utilized In-depth Interview and Focus Group Discussion to determine the traces of ato as a judicial institution in the Lupon. In-depth Interviews and FGDs were used by this researcher to identify the processes in implementing and evaluating policies as part of the public administration practices of the Lupon. Also, these methods were used to identify the Lupon's way in solving conflicts and imposition of sanctions.

\section{METHODOLOGY}

This chapter presents the methods and procedures of the study. It includes the description of the research design, population, and locale and how the data was collected.

Research Design

The study utilized a qualitative design. A descriptive approach was used because it is the best way to capture the responses of the informants regarding their beliefs and ideas on the traces of ato as a judicial institution in the Lupon. In addition, the researcher also utilized the interpretive paradigm which hinges on the belief that the responses of the informants will be taken as valid answers that can be used to produce a new knowledge such as language, consciousness and shared meaning (Myers, 2009).

\section{Population and Locale of the study}

Talubin is one of the 16 Barangays in the municipality of Bontoc. It is located in the western geographical side of the municipality and shares a common border with barangay Bayyo, Gonogon, Barlig, Can-eo, Alab, and Samoki. It is currently divided into two (2) sitios: Vabley and Doddo. Its population as of 2015 is 1,673 (Philippine Statistics Authority, 2015), representing 6.79\% of the total population of Bontoc. 
International Journal of Management, Entrepreneurship, Social Science and Humanities (IJMESH) Vol. 4 (1), 76-95

Traces of Ato as a Judicial Institution in the Lupon of Barangay Talubin, Bontoc, Mt. Province

A. G. Killip Jr

The researcher used a purposive sampling and referral method in gathering the informants of the study. The informants of the study were the current five (5) members of the Lupon, including the three (3) barangay officials in Talubin. The informants were chosen based on their current role as the mediators and arbitrators of dispute settlement and conflict management, and as local public administrators.

The five (5) members of the Lupon have no academic degrees. Their expertise and experience on customary laws and traditional practices of the community supplement what they know about their functions as prescribed by the Local Government Code of 1991 especially on their role in the implementation and evaluating policies in the Lupon.

The highest educational level attained by three (3) of the barangay officials was secondary education. The barangay officials have a knowledge on the general scope and limits of their administrative functions in the barangay. However, the researcher observed that they did not follow the legal provisions of the Local Government Code of 1991 which states that Lupon must consist of 10 to 20 members; since the barangay officials only picked five (5) members who are below the minimum as prescribed by the Local Government Code.

\section{Data Gathering Tools}

The researcher used the following tools in the study:

1. In-depth interview. The researcher conducted an in-depth interview with five (5) current members of the Lupon and three (3) barangay officials. The researcher conducted an in-depth interview to explore their perspectives on judicial and administrative practices and to elicit a vivid picture of their perspective on the research topic.

In addition, the researcher also used an interview guide to come up with detailed information about the informants' thoughts and behaviors. The contents of the interview guide revolved on the judicial and administrative practices of the Lupon, specifically the processes in implementing and evaluating policies, and processes in conflict resolution and imposition of sanctions.

2. Focus Group Discussion. The researcher also utilized a Focus Group Discussion so that he could observe the interaction of the eight (8) informants in a limited time. The researcher utilized Focus Group Discussion in the form of "tungtungan" as a way of interacting with the Lupon members and officials of the barangay.

Focus Group Discussion helped the researcher in gaining insights on the informants' perspectives on the topic of discussion.

\section{Data Gathering Procedure}

The researcher, having the prepared documents for the conduct of the study, traveled from Baguio City to Talubin to gather the necessary data and meet the informants of the study personally. The researcher met with the barangay captain and asked for permission to conduct a study.

The barangay captain was the first one to be interviewed. During the interview, the researcher asked questions that are related to the traces of ato as a judicial institution. After the interview with the barangay captain, the researcher looked for the other barangay officials to be interviewed. Unfortunately, only two (2) barangay kagawads were available during the stay of the researcher in the community. In the following days, the researcher successfully interviewed all the five (5) members of the Lupon in their respective houses. 
Furthermore, after the one-on-one interview with the informants, the researcher asked the permission of the barangay captain for a Focus Group Discussion with the participation of all the informants who were interviewed individually. The barangay captain approved the request and set the schedule of the FGD at the Barangay Hall.

The informants present during the focus group discussion were the five (5) members of the Lupon and only three (3) officials, including the barangay captain.

The researcher translated the questions to the Italubin and Ilokano dialects to ensure that the informants will answer the questions correctly and that will interact comfortably with the researcher. The researcher quickly established rapport with the informants because the researcher is a part of the community, having lived there during his younger years.

\section{Treatment of Data}

The researcher used the following approach in the treatment of data:

Thematic analysis. The researcher took note of the responses of the informants with the aid of an audio recorder which the informants allowed to use. The responses of the informants were coded word by word. The researcher coded the responses of the participants that were related to the research questions of the study. The researcher tried to elicit other responses that are not suited to findings of the study.

Content Analysis. The study utilized the content analysis to determine the presence of a specific meaning within the responses of the informants. The researcher was able to analyze the meanings and relationships of the responses of the Lupon members and barangay officials from the In-Depth Interview and Focus Group Discussion.

\section{Ethical Consideration}

The researcher followed the protocol in research ethics. The researcher took the endorsement of the adviser and approval of the dean of the University of Baguio, School of Liberal Arts and Human Sciences. The researcher also sought the approval of the National Commission on Indigenous Peoples (NCIP-CAR) Regional Office to commence the study. The researcher delivered a request letter, endorsed by the adviser and the Graduate School dean, to the Barangay Chairperson of Talubin, requesting permission to conduct the study in the barangay. With the approval of the barangay captain, the researcher showed the interview guide to the members of the Lupon and the officials.

The researcher explicitly asked the informants on their consent regarding their participation in the study and read the consent form to them. The said form contained the anonymity, privacy and confidentiality conditions. Moreover, during the conduct of the study, the researcher tried to be sensitive in asking questions to the informants and assured them that the findings of the study will be utilized for the purposes of this research only.

The researcher also tried to be as ethical as possible when interpreting the study results based on the responses of the eight (8) informants from barangay Talubin. To do so, the researcher used triangulation techniques in interpreting the data through interviews from the informants, personal observations in the context of the study and used other studies as a reference to corroborate the findings. After the finalization of the study, the researchers presented the output to the members of the Lupon to discuss the result; and eventually extended gratitude for their participation. 


\section{RESULTS AND DISCUSSIONS}

This chapter presents the analysis and interpretation of the findings on the traces of Ato as a judicial institution in the Lupon of Talubin, Bontoc, Mt. Province. It also presents the public administration practices and the judicial practices in the Lupon.

\section{Public Administration Practices in the Lupon}

During the interviews and FGD sessions, the informants conveyed their belief systems and knowledge on the public administration practices specifically on the processes in implementing and evaluating policies by the Lupon. The integration of legal and cultural-related processes is one of the unique features of the public administration practices of the Lupon. The said processes help the Lupon in implementing the legal norms and methods of management processes and procedures as a regulatory, organizational, and a judicial body (Mladen, 2015). During the interview, the researcher found out that the Lupon and the Sangguniang Barangay are two distinct bodies that complement each other in mobilizing the public and preserve the peace within the community.

However, the researcher also found out that the Lupon does not have administrative functions in the Barangay. It is the Sangguniang Barangay who has administrative functions such as the implementation and evaluation of the policies for the community. Hence, this researcher was not able to extract any data on the administrative practices of the Lupon. Instead, this researcher gathered fragments of ato currently utilized by the Lupon in support of the administrative functions of the Sangguniang Barangay.

\section{The Processes in Implementing Policies}

It is part of the study to determine the administrative practices of the Lupon, specifically its processes in implementing policies in the community. The researcher extracted data on the process of implementing Barangay ordinances instead of policies. Nevertheless, the researcher still chose to present the gathered data related to the implementation of ordinances. The researcher did this to address the main objective of this study, to determine the traces of the ato as a judicial institution in the Lupon of Barangay Talubin. The role of the Lupon in implementing ordinances involves legal and cultural- related processes.

\section{Review by the Barangay Chairperson}

In any Barangay, the official who holds the executive office is the Barangay Chairperson. His role includes maintaining public order, call and preside over sessions, and exercise general supervisions over the activities of Sangguniang Kabataan.

In addition, the role of the Barangay Chairperson is to review proposed ordinances for the approval of implementation, enforce all laws and ordinances which are applicable within the Barangay, and other administrative functions as mandated by the Local Government Code. In the implementation of the ordinances, the Barangay has the discretion to implement a specific ordinance or not. In Barangay Talubin, the administrative functions of the Barangay Executive Office as indicated by the Local Government Code are practiced by the Barangay Chairperson as the chief executive.

The participants also mentioned that during the deliberation, the role of the Barangay Chairperson is to facilitate the deliberation of the Barangay legislative committee and to some 
extent, ask questions regarding the proposed ordinance. The Barangay Chairperson is not allowed to vote for the passage of the proposed ordinance, but in cases of a tie in a vote, it is the role of the Barangay Chairperson to break the tie. In some instances, the Barangay Chairperson can also propose an ordinance, but during the deliberation, he will no longer act as the facilitator. The firstin-rank kagawad will preside the meeting.

The role of the Barangay Chairperson during the deliberation is to defend his proposed ordinance to the legislative committee. Once the proposal is approved by the body it will be automatically implemented. Thus, the researcher concludes that in Barangay Talubin, the legislative body is composed of the Barangay kagawads, whose role is to discuss and debate upon the proposed ordinance during the session. The Barangay Chairperson presides the said session, and if the proposed ordinance is approved, then it will go directly to the office of the Barangay Chairperson for the last review and approval. The capacity of the Barangay Chairperson to approve or disapprove the proposed ordinance relies on the executive power vested upon him as the Barangay chief executive.

\section{Posting of the Ordinances in the Barangay Hall}

The mandate of the law to let the public be aware of the newly implemented laws, ordinances, memorandum and any necessary documents that cater to the concern of the public applies to both the national and local government. It is a mandate of the law that every local institution must inform the people of any important notice in any matter that involves public concern by posting such notice in three (3) conspicuous places within the community.

In the Barangay level, dissemination of information regarding the ordinances that was crafted by the Barangay officials is one of the significant parts of the implementation of the policy. Letting the people know the content of the said ordinance permits a smooth implementation of the said ordinance.

The posting of ordinances in the Barangay Hall is also a mandate of the Local Government Code of 1991 stating that public documents and other matters that must be known by the public must be posted in the conspicuous places of the Barangay. In addition, posting of ordinances in the Barangay Hall will allow the Barangay officials to be transparent to the people on the ordinances they created.

It was observed by the researcher that posting written ordinances in the Barangay hall is the usual strategy. However, this information dissemination strategy seems to be lacking. It would be better if these written ordinances are printed poster-style.

\section{Printed poster-style communications are posted in strategic places}

For anti-dumping of garbage ordinance, the Barangay officials post big posters near canals, ditches and gutters stating that "bawal magbasura dito, multa 500 pesos" (no dumping of garbage here, fine 500 pesos). There are also some posters in public places like the plaza stating that "awan agtuptupra ti momma ditoy, multa 500 pesos" (no spitting of momma here, fine 500 pesos). Lastly, some ordinances like "no selling of liquors and cigarettes to minors, fine 1000 pesos" are posted in front of the different stores of the Barangay. Hence, the researcher concludes that the legal process in implementing policies involves the review by the Barangay Chairperson on the proposed ordinances from the legislative committee. Once the ordinance is approved, its content is posted at the Barangay Hall for easier accessibility to the people. Warning posters and slogans are also posted 
International Journal of Management, Entrepreneurship, Social Science and Humanities (IJMESH) Vol. 4 (1), 76-95

Traces of Ato as a Judicial Institution in the Lupon of Barangay Talubin, Bontoc, Mt. Province

A. G. Killip Jr

in the different designated places in the Barangay to inform the people on the newly approved ordinance.

\section{House-to-house information drive by the Barangay tanod}

The researcher observed that the officials of Barangay Talubin follow a hybrid process (a combination of a legal and cultural-related process) in implementing ordinances.

This researcher found that there is a cultural-related process in implementing ordinances. This process involves a traditional practice of informing the people on matters that involve public concerns. Accordingly, the elders of the ato had already come up with a means of informing the people on the matter that involves cultural-related activities such as community gathering or meeting, tengao, holidays, burial of the dead, or even the preparation for tribal war. The Lupon appoints a person to act as an announcer who roams around and broadcasts to the community all matters pertaining to communal activities.

The traditional process of information drive was carried out as a role of the tanods of the Barangay. The tanods are mandated to disseminate the content of the ordinance to the people and watch over the implementation of all the Barangay ordinances.

The practice of informing the people of newly crafted ordinance through the house-tohouse information drive by the tanods is a traditional practice of the community. Although, the role of informing the people on the matter of public concern was once assigned to person chosen by the elders of ato. The reason why such practice is still being used today, and is adopted as part of the process in implementing ordinances by the Lupon is to ensure that all people are well informed and updated on what is happening in the Barangay.

The findings point to the supporting role of the Lupon in the administrative functions of the Sangguniang Barangay. However, the Lupon still has a significant function in maintaining peace and order, administering justice and political mobility in the Barangay and other agencies of the local government.

The researcher observed that the primary role of the Lupon is to arbitrate conflicts within the Barangay and to support the administrative functions of the Sangguniang Barangay. Hence, a collaboration between the barangay officials and the Lupon members is necessary. A dialogue between them ensures that the appropriate ordinances will be prioritized and implemented well. Based on the summative responses of the informants, ordinances that are anchored on the existing government memorandum and under the constitutional mandate of the national government are within the political power of the Barangay officials to implement. The crafting and execution of customary practices and traditions are within the authority of the Lupon members and Barangay officials.

\section{Judicial Practices in the Lupon}

The Lupon is considered to be an alternative avenue for the people to settle their conflict amicably. It is a facet of the government institution that is critical in maintaining peace and security within the community. The judicial practices of the Lupon involve the integration of legal and cultural-related processes in conflict resolution and imposition of sanctions. On the other hand, the national government passed the Republic Act No. 9285 also known as "An act to Institutionalize the use of an Alternative Dispute Resolution System in the Philippines and to establish the office for Alternative Dispute Resolution, and other purposes." The said R.A. declares the policy of the state 
International Journal of Management, Entrepreneurship, Social Science and Humanities (IJMESH) Vol. 4 (1), 76-95

Traces of Ato as a Judicial Institution in the Lupon of Barangay Talubin, Bontoc, Mt. Province

A. G. Killip Jr.

to actively promote party autonomy in the resolution of disputes or the freedom of the party to make their arrangements. The use of Alternative Dispute Resolution (ADR) is highly encouraged by the government to be used by conflicting parties because it is an essential means to achieve faster and impartial justice.

\section{The Processes in Evaluating Policies in the Lupon}

The data gathered by the researcher show that there is no process in evaluating policies in the Lupon nor any procedure similar to it. Instead of discussing the evaluating process of the Lupon, the researcher discussed the process in evaluating the performance of the Lupon.

\section{Observation by the Barangay Chairperson}

The Lupon members are also the elders of the ato. They are considered to be experts in customary laws and implementers of the traditions in the community. The Barangay Chairperson has the power to choose the members of the Lupon will be as guided by the provisions of the Local Government Code of 1991. The evaluation of the performance of the Lupon is the basis of the Barangay Chairperson to determine the effectiveness of the Lupon members in fulfilling their role in the community.This was also supported by one of the members of the Lupon who witnessed someone removed from being a Lupon member because that person did not contribute anything to the discussion during conflict resolution. If a member of Lupon will not perform well his duty, then, the Barangay Chairperson can remove him because there is no need for him to stay in his position.

The responses of the informants show a collective agreement that not all elders of the ato who were appointed as members of the Lupon can show their expertise in the conflict resolution. They were not also competent enough to do administrative functions. Furthermore, there is no standardized tool to evaluate the performance of each member of the Lupon. The Barangay Chairperson can evaluate them through their skills and abilities in articulating their ideas in the public, argue on the matter related to conflict resolution. It is also part of their duty to convince the people that their decision is valid based on their resounding experience and wisdom. Moreover, people will expect them to be able to resolve conflicts and provide a solution to problems.

Lastly, the public also expects them to possess non-cognitive abilities such as integrity, honesty, credibility, and trustworthiness. They also need to be attentive to community issues and problems. Lastly, they should be friendly, loving, sociable, sympathetic, merciful, and have the right attitude towards the people.

The power of the Barangay Chairperson to remove an incompetent member of the Lupon is anchored on his authority to choose who will be the members of the Lupon will be as stated under the Local Government Code of 1991. The Code provides that the Lupong Tagapamayapa or referred to as Lupon shall be composed of the punong Barangay as the chairman and ten (10) to twenty (20) members. The members can be any person who is residing or working in the Barangay, not otherwise expressly disqualified by law. The candidate for the member of a Lupon shall possess integrity, impartiality, independence of mind, sense of fairness, and reputation for probity. In Barangays where a majority of the inhabitants are members of indigenous cultural communities, local systems of settling disputes through their councils of datus or elders shall be recognized without prejudice.

Hence, as stated by Weatherbee (n.d.), the calls for the evaluation of the quality of governance and attainment of relevant goals such as securing and defending the integrity of the community is essential. The quality of governance will ensure public order and domestic security, promoting political, social, and economic policies in the interest of the public. Good governance 
International Journal of Management, Entrepreneurship, Social Science and Humanities (IJMESH) Vol. 4 (1), 76-95

Traces of Ato as a Judicial Institution in the Lupon of Barangay Talubin, Bontoc, Mt. Province

A. G. Killip Jr

implies that political authority is reflective of the capability of the leader to effectively promote the welfare of the people.Judicial Practices in the Lupon

The Lupon is considered to be an alternative avenue for the people to settle their conflict amicably. It is a facet of the government institution that is critical in maintaining peace and security within the community.

Judicial practices on conflict resolutions in the Lupon

The judicial practices on conflict resolutions are divided into three phases: before the hearing; during the hearing; and, after the hearing. The perceptions and beliefs of the Lupon members were conveyed through their personal experiences on the judicial practices on conflict resolutions in the Lupon.

\section{Before the hearing}

In the first phase of the conflict resolution, the conflicting parties reach out for the help of the Barangay officials and the Lupon members. Based on the data gathered, the initial act of the conflicting parties in seeking help from the Barangay authorities establishes a ground for trust between the conflicting parties, the Barangay officials and the Lupon members which shows that all the parties involve can help each other to solve conflicts.

The typical answer of the informants, when asked on the procedures in accepting cases, is, "nu kayat da umay kadakami" (if they want to consult with us). This indicates that while it is the role of the Lupon to arbitrate disputes and conciliate both parties, the latter must be willing to relay their issues and conflicts to the Lupon.

In addition, a person involves in the conflict or dispute wanted to seek for the help of the Lupon implies that the willingness of both parties to relay their conflict to the Lupon is a significant step for conciliation or openness for settling of dispute.

Thus, in accepting a case, the paramount consideration is the willingness of both parties to listen to the Lupon members. If both parties shows that they are willing to settle their conflict in the Lupon, then the Lupon members can set the time and date of the hearing of the case.

\section{During the Hearing}

The judicial practices proceed to the second phase of the conflict resolution process after both parties have sought the help of the Barangay officials and Lupon members. The second phase is divided into two series of processes. The first process involves mediation through private council conference, which involves only the Barangay officials and the involved parties. The second process involves arbitration through a public hearing.

Mediation through private Council Conference. In the local level, the Barangay officials can act as the mediators during the hearing of a case. They also facilitate the discussion and allow a responsive communication between the two parties. The Local Government Code of 1991 also stated that when the Barangay Chairperson received a complaint, he can immediately summon the respondents and the complainants for mediation if the mediation effort of the Barangay Chairperson fails within fifteen (15) days.

The hearing will be done privately, with the presence of the Barangay officials and the two parties. The reason for a close door conference is to ensure that the interest of privacy and decency of both parties are protected. The role of the Barangay officials is to facilitate the discussion and 
International Journal of Management, Entrepreneurship, Social Science and Humanities (IJMESH) Vol. 4 (1), 76-95

Traces of Ato as a Judicial Institution in the Lupon of Barangay Talubin, Bontoc, Mt. Province

A. G. Killip Jr.

resolve the conflict through mediation. They do not impose any judgment but guide them to come up with a solution to their conflict or problem.

Arbitration through Public Hearing. The arbitrators are the members of the Lupon who had been appointed by the Barangay Chairperson. Their specific role is to resolve disputes of the parties through amicable settlement before it reaches the higher courts.

If the Barangay officials cannot resolve the conflict, then that is the time to seek help from the Lupon. The Lupon will discuss or "pangtungtungan" the matter in a public hearing or "tongtong" through arbitration by using their knowledge and expertise on customary laws.

One of the traces of ato as a judicial institution in the Lupon is the settlement of disputes by way of tungtungan. The tungtungan is a traditional practice of the ato in resolving disputes in the community. It is an amicable discourse in setting a pleasant atmosphere between two parties to come up with an amenable agreement through the help of the elders of the ato as the arbiters. After reaching a certain point of the arrangement, the elders seal the agreement through some rituals. A violation of the said agreement can lead to tribal war. The adoption of Lupon members of the tungtungan denotes its sanctity as a means of resolving disputes.

On the other hand, the community is welcome to join in the discourse during the arbitration. The role of the Barangay officials during the arbitration is to approve and support whatever the decision of the Lupon and the public will be.

The protocol of Lupon before the start of the public hearing is to make both parties take an oath or sapata that everything they will say during the public hearing will only be the truth. Another trace of the ato as a judicial institution in the Lupon is the observance of the traditional practice of sapata. The elders believe that sapata is a sacred means of imploring the gods for justice. In this way, the individuals will have to be truthful in the words they utter. It can be inferred by the researcher that the adoption of sapata as part of the arbitration process is a manifestation of the Lupon members' and community people's belief on the existence of a supernatural being. This supernatural being guides the arbitration process.

The Lupon also believes in the power of sapata. The power of sapata is seen in the consequences of the words he/ she utters during the public hearing.

The primary role of the Lupon is to help conflicting parties settle their differences through amicable settlement. The settled agreement shall be in writing in a language or dialect known to the parties and signed by them. The agreement must be attested by the Lupon chairman or the pangkat chairman, as the case may be. The Lupon needs to meet regularly, once a month, to provide a forum for the exchange of ideas among its members and the public on matters relevant to the community. The meeting will also discuss the process to deal with amicable settlement of disputes. Furthermore, the meeting will enable various conciliation panel members to share their observation and experiences in effecting a speedy resolution of disputes.

All amicable settlements shall be in writing in a language or dialect known to the parties. The settlement must be signed by both parties and shall be attested by the Lupon chairman or the pangkat chairman. Moreover, no complaint involving any matter within the authority of the Lupon shall be filed or instituted directly in the court or any other government office for adjudication, unless there has been a confrontation between the parties before the Lupon chairman or the pangkat.

It was also outlined in the Local Government code that amicable settlement is a process that needed to be fulfilled. It is a mandate by the Local Government Code that no complaint involving 
International Journal of Management, Entrepreneurship, Social Science and Humanities (IJMESH) Vol. 4 (1), 76-95

Traces of Ato as a Judicial Institution in the Lupon of Barangay Talubin, Bontoc, Mt. Province

A. G. Killip Jr

any matter within the authority of the Lupon shall be filed or instituted directly in the court or any other government office for adjudication. The exception on the direct filling of case in the Lupon is when there has been a confrontation between the parties before the Lupon chairman or the pangkat, and that no conciliation has been reached. That result of the amicable settlement should be certified by the Lupon secretary or pangkat secretary as attested to by the Lupon or pangkat or unless the parties have repudiated the settlement.

The Lupon of Barangay Talubin indeed was created to fulfill the goal of the barangay judicial institution. However, the use of customary laws does not automatically settle the conflict. It is also essential for the Lupon members to convince both parties to make decisions for their own good. The Informants used the phrase, "Pamagvaga ken isuda"(advice to them), to make both parties realize the mistakes that they committed and the consequence that they will suffer if they will not change their behavior. This statement denotes that one of the critical roles of a Lupon member is to make the two parties realize that engaging into a conflict is a lost battle. Thus, it is a must to reconcile both parties to ensure peace and order in the Barangay.

In conclusion, the process of conflict resolution supplements the conflict management by the amicable settlement of the Local Government Code through the Lupon of the Barangay.

After the Hearing

Compliance of both parties. One traditional way of ensuring the compliance of both parties on the written agreement is to have a sapata. Sapata is an oath for the gods that a party will follow what has been agreed upon such as "nu haan ko suruten ket agsakitak "(if I do not comply then I will get sick) or "nu haan ko suruten ti napagtutungtungan ket matay ak" (if I do not comply with the agreement then I will die). The non-compliance to a sapata can cause misfortune to the person. The researcher would like to emphasize that there are two sapata in the conflict resolution process. The first sapata was conducted during the hearing, specifically before the arbitration through a public hearing, and the second sapata was conducted after the hearing for the compliance of both parties. The second sapata is also a fragment of ato's judicial practices that were adopted by the Lupon. Both parties involved in the conflict must take an oath to the gods that they will comply on what was agreed upon during the conflict resolution.

The Lupon members believe that sapata is a useful tool in making both parties comply with the agreement. They also explained the effectiveness of sapata, that there are already two people who took an oath but did not comply with the agreement, both of them suffered, and the other person died.

The researcher infers that the practice of Lupon in hearing cases is patterned on how the ato solves disputes, which is considered by Prill-brett (205) as a Village "Court." Village court creates an avenue to publicize hearing of cases that allows the community to voice out their opinions and criticize the decisions.

Judicial Practices on Imposing Sanctions in the Lupon

The judicial practices of the Lupon on the imposition of sanctions apply only to the criminal case and non- compliance of one or both parties on their written agreement. It is a unanimous agreement by the Lupon members and Barangay officials that criminal charges against a particular individual are always discussed and solved in the Lupon before they reach the courts. Such charges include physical assault, vandalism, theft, public scandal, and unjust vexation. It is the Lupon and the community who shall determine the corresponding punishment to such acts. The punishment may be community service or fines. 
However, the researcher noted that the Lupon did not establish a standard procedure in determining its jurisdiction on the cases that can undergo amicable settlement. The power of the Lupon members to determine the penalty of offenses and even the process, grounds, and effects of repudiating the agreement of the case was not established. Hence, the researcher can only give a discussion on the matters involving the current practice of the Lupon in imposing sanctions.

\section{Legal Practice}

Memorandum of agreement. The offender and the offended party need to sign a written agreement stating that their conflict has been resolved. Some Barangay officials mentioned that the written agreement of the case being settled is a necessary document that should be submitted to the Municipal trial court for record purposes. They also added that in cases of a violation of Barangay ordinances, the violator of our Barangay ordinance should sign a written agreement regarding his acceptance of the offense he committed and promise that he will not commit the same act again.

\section{Cultural-related practice}

Penalize the offender. It is common for the Lupon to impose fines as part of sanctions to the offenders. The penalty of their offense depends on the decision of the members of the Lupon. The penalty of the offender can be in the form of money, livestock, dwellings, or personal belongings such as clothing and utensils. The members of the Lupon must agree upon the penalty to be imposed. The penalty is base on the gravity of the offense committed and the capacity of the offender to pay the penalty. For instance, if a person steals palay, the injured party may take a field from him. If a man is caught stealing pine wood from the forest of another, all the wood he has cut and his working ax will be taken away from him. A fine of chickens, pigs, rice fields, sometimes even of carabaos, is the usual penalty for assault and battery. These imply that fines or penalty of the offender are based on the customary practices.

Aside from fines, the Lupon members can also require the offender to render community service as a penalty to his/her offense. Community service includes cleaning up essential areas for the Barangay such as highways, Barangay Hall, or even canals or river. This requirement from the Lupon is an alternative sanction to the offender if the latter cannot afford to pay the fines imposed by the Lupon. Community service is a social work that is performed without pay, which highlights public service and gives a chance to the offender to be rehabilitated and be integrated into the community. All these circumstances presented by the researcher show that the process of imposing sanctions to a specific person for his/her violation of Barangay ordinance is affixed on the legal process mandated by the local government. However, the cultural practices that are currently utilized by the Lupon members such as their flexibility in choosing the mode of payment of fines deviate from the mandate of the law. The sole discretion of the Lupon members is choosing the modes of payments for fines which was allowed by the Barangay officials.

Overall, the researcher can infer that the study was able to present the integration of cultural and legal processes in public administration and judicial practices of the Lupon in the Barangay. Some of the traces of ato as a judicial institution were carried out by the Lupon, which are still recognized by the Barangay. 
International Journal of Management, Entrepreneurship, Social Science and Humanities (IJMESH) Vol. 4 (1), 76-95

Traces of Ato as a Judicial Institution in the Lupon of Barangay Talubin, Bontoc, Mt. Province

A. G. Killip Jr

\section{CONCLUSIONS}

The Barangay Chairperson chooses the elders of ato to be the members of the Lupon because the barangay officials believe that elders are competent in fulfilling their role in the community based on their knowledge and expertise in customary laws. The traces of ato in the public administration practices and processes of the Lupon highlight the process of information dissemination of newly crafted ordinance. The information dissemination is done through houseto-house information drive, which is an old practice of the ato. The responses of the informants on the traces of ato in the public administration of the Lupon show that the people have strong acceptance on the cultural practices of the ato.

The traces of ato in the judicial administration practices and processes of Lupon were shown in the conflict resolution and imposition of sanctions of the Lupon. In the conflict resolution practices and processes of the Lupon, the study highlights "sapata" and "tongtong" as the significant traces of ato in the Lupon. The significant traces of ato in the judicial administration of the Lupon show the definite impact of the customary practices and processes in dispute resolution and conflict management among the members of the community. The said customary practices in dispute resolution help the people achieve a responsive justice associated with the customs and traditions of the community.

Based on the findings of this research, the researcher recommends the following:

1. The Lupon should have a defined jurisdiction over the nature of disputes that should be settled through mediation and arbitration and a clear delimitation on the role of the Lupon on the imposition of penalties to the violators of the ordinances.

2. The Lupon should have clear repudiating grounds and procedure on the cases that were not settled even after the arbitration process.

\section{REFERENCES}

Asia Indigenous People's Pact (2007). Indigenous governance system of Asia. Asia's Conference on Indigenous Governance.

Baring J. C. \& Gaspar, K. (2013). The Kankana-ey's hope for reclaiming the significance of their culture and rituals. Davao City.

Brillantes, A. Jr. \& Fernandez, M. (2005). Is there a Philippine public administration? Or better still, for whom is Philippine public administration. Asian Development Bank.

Botengan, K. C. (1976). Bontoc life-ways: A study in education and culture. Centro Escolar University Research and Development Center. Capitol Publishing House.

Boyce, C. \& Neale, P. (2006). Conducting in- depth interview: A guide for designing and conducting in- depth interviews for evaluation input. Pathfinder International Tool Series.

Bryman, A. (2012). Social research methods. Oxford University Press. University of Oxford.

Campbell, M. S. (2015). The Right of indigenous peoples to political participation and the case of Ytama V. Nicaragua. Arizona Journal, State of Arizona

Cawed, C. (1972). The culture of the Bontoc Igorot. R.P. Manila City: GARCIA Publishing Co.

Cordillera Schools Groups, Inc. (2003). Ethnography of the major ethnolingguistics groups in the Cordillera. Quezon City: New Day Publishers. \& Comparative Law, 21 (1), pp. 271-299.

Crocombe, Ro. (1974). "An approach to the analysis of land tenure systems." In Land Tenure Oceana, edited by Henry P. Lundsgaarde, 1-17. Honolulu: University of Hawaii Press. 
International Journal of Management, Entrepreneurship, Social Science and Humanities (IJMESH) Vol. 4 (1), 76-95 Traces of Ato as a Judicial Institution in the Lupon of Barangay Talubin, Bontoc, Mt. Province A. G. Killip Jr.

Cultural \& Survival. (2017). Philippines: Traditional justice system used to resolve conflict. Massachusetts Avenue Cambridge. Retrieved on August 20, 2018 from https://www.culturalsurvival.org/news/philippines-traditional-justice-system-usedresolve-conflicts

De Guzman, R. P. (1986). Is there a Philippine Public Administration? Philippine Journal of Public Administration, $30(4)$, pp. 2-9.

De Leon, Hector. S. \& De Leon Hector. M. Jr. (2011). Textbook on the Philippine Constitution. Manila City: Rex Book Store.

Disini Jr., Domingo P., Aguiling-Pangalangan, E., Daroy-Morales, R. E.V., Gatmaytan, D.B., LimJardeleza, C. (2002). Dispute resolution mechanisms in the Philippines. Chiba, Japan: Institute of Developing Economics.

Domingo, Ma. (2004). Indigenous leadership and governance. Philippine Journal of Public Administration, 48(1-2), pp. 30-40.

Dooly, M., Moore, E. \& Vallejo, C. (2017). Research ethics. Dublin, Ireland: Research-publishing.net.

Glaser, B. (1965). The constant comparative method of qualitative analysis. Sound Problems, 12(4), pp. 436-445.

Hamaya, S. \& Oya, T. (2013). Phronetic leaders: Designing leaders: Designing new business, organisation and society. Fujitsu Research Institute.

Ivision, D., Patton, P., Sanders, W. (2000). Political theory and the rights of indigenous people. United Kingdom: Cambridge University Press.

Jenks, Albert E. (1905). The Bontoc Igorot. Manila: Bureau of Printing.

Lawrence, S. V. \& Martin, F. M. (2013). Understanding China's political system. Congressional Research Service.

Maguire, M. \& Delahunt, B. (2017). Doing a thematic Analysis: A practical, step-by-step guide for learning and teaching scholars. All Ireland Journal of Teaching and Learning in Higher Education, 8(3), pp. 3352-3354.

Manengyao, G. P. (2016). Pechen: Its role in conflict resolution. London City: Agshan $\quad$ Word press.

Manyong Victor, M. \& Houndekon Victorin, A. (2000). Land tenurial systems and the adoption of Mucuna planted fallow in the derived Savannas of West Africa. Capri Working paper, $4 \mathrm{p}$. 42.

Martin, R. (1975). Ethics: Two models for justifying political authority, 86(1), p. 70.

Mladen, R. (2015). Conflict management in public administration using knowledge bases and new software solution. International Journal of Application or Innovation in Engineering \& Management (IJAIEM), 4(2), pp. 108-112.

Mogashao, T. (2014). Understanding critical discourse analysis in qualitative research. International Journal of Humanities Social Science and Education, 1, pp. 107-110.

Molintas, J. M. (2004). The Philippine indigenous peoples' Struggle for land and life:Challenging legal texts. Arizon Journal of International

Myers, M. (2009). Qualitative research in business \& management. Thousand Oaks, California: Sage Publications.

National Alternative Dispute Resolution Advisory Council (NADRAC). (2006). Indigenous dispute resolution and conflict management. Australia: NADRAC Publication.

Prill-Brett J. (2015). Tradition and transformation: Studies on Cordillera indigenous culture, 
International Journal of Management, Entrepreneurship, Social Science and Humanities (IJMESH) Vol. 4 (1), 76-95

Traces of Ato as a Judicial Institution in the Lupon of Barangay Talubin, Bontoc, Mt. Province A. G. Killip Jr

edited by Delfin Tolentino Jr. Cordillera Studies Center, University of Philippines- Baguio.

Prill-Brett J. (1987). Pechen: The Bontok Peace Pact Institution. Cordillera Studies Center, University of the Philippines Colleges- Baguio.

Walker, D. \& Lambert, L. (1995). Learning and leading theory: A century in the making. New York: Teachers College Press.

Weatherbee, D. E. (n.d.). Governance in Southeast Asia: The good, the bad, and the ugly. AsiaPacific Center for Security Study, 15(4), pp. 179-181. Retrieved on August 15, 2018 from https://apcss.org/Publications/Edited\%20Volumes/GrowthGovernance_files/Pub_Growt h\%20Governance/Pub_GrowthGovernancech14.pdf 